\title{
SOLVING HOMELESSNESS WITH ARCHITECTURAL ORGANISATION OF RESIDENTIAL BUILDING COMPLEXES IN NIGERIA
}

\author{
(C) I.B. Adejuyigbe ${ }^{1}$, V.M. Shuvalov ${ }^{1}$, E.A. Akintaro ${ }^{2}$ \\ ${ }^{1}$ Peoples Friendship University of Russia (RUDN University), Moscow, Russia \\ ${ }^{2}$ Federal University of Technology, Akure, Nigeria
}

\begin{abstract}
The importance of shelter to man cannot be overemphasised. According to the Managing Director of Federal Mortgage Bank of Nigeria (FMBN) in 2018, Nigeria's housing deficit is estimated at between 17 to 20 million housing units, increasing annually by 900000 companies, with a potential cost of N6 trillion (US\$16 billion). This paper examined how a lack of affordable housing has contributed to homelessness in Nigeria and establishes using the architectural organisation of residential building complexes as one of the major solutions to the shortage. With the use of three (3) objectives, the study finds out the influence of affordable housing on homelessness, to investigate the level of homelessness accrued to lack of affordable housing in Nigeria and to determine the architectural strategies that can be used to ensure affordable housing in Nigeria. In order to streamline the study, a case study of Mowe, Simawa in Ogun State was chosen, and questionnaires were administered to investigate the research problem. The study shows that if housing is not within an affordable range, then the victory over homelessness is far from over. It concludes that affordable housing is entirely possible. Considering all necessary factors and homelessness will be a thing of the past in the nearest future with an architecturally organised residential building and proper management.
\end{abstract}

Keywords: Affordable, homelessness, housing, construction, residential building, complexes, architectural

\section{INTRODUCTION}

The importance of shelter to man cannot be overemphasised. Not only does shelter serves as a covering over man, but it also enables man to have its privacy. In his bid to ensure a cover over his head usually tries all means to provide a place of shelter. In line with this, (Osasona, Ogunshakin \& Jiboye, 2007; Jiboye, 2009) explained that man in his quest for adequate shelter has consistently tried to reshape his immediate environment a means of cover and protection from the external elements. Man needs shelter for protection from natural ingredients such as rain, sun, and moon, human and animal attacks. However, despite Man's consistent effort to provide shelter, many people are still homeless, which is influenced by their inability to afford a decent place.

As defined by Wright (2007), "is the condition of people who lack regular legal access to adequate housing". People who cannot afford the demand for acquiring a place of shelter. These set find themselves sleeping and living under the bridge, uncompleted buildings, mosques, churches and other public places. They are usually victims of attacks such as rape, robbery etc. because they need survival, they get engaged with illegal jobs such as robbery, call girls, and touting. Thus, the housing need has been an issue of global concern as the housing provision remains one of the intractable problems facing humankind (Konadu-Agyemang, Noonam, \& McCord, 1994). There is a worldwide acknowledgement that housing is one of life's necessities and a barometer for gauging development yet; its provision is short supply. (Douglass, 2008). The government and other partners' prompt intervention is needed to revive the homeless's hopes and expectations towards a better and improved living condition.

The situation in Nigeria is by no means different. The population living within the urban centres increased phenomenally over the years; rising from an initial $7 \%$ in the 1930 s to more than $10 \%$ in the fifties. The figure rose from $20 \%$ in the seventies to about $27 \%$ and $35 \%$ in 1980 s and 1990s, respectively Jiboye (2011:139). During these periods, particularly the oil boom era in Nigeria, major cities, including Lagos, witnessed a massive influx of the rural dwellers (Metz, 1991; Jiboye \& Omoniyi, 2010). However, a United Nations (2007) report on Nigeria had indicated an urban growth 
rate of $5.8 \%$ annually. The report estimated that over $43 \%$ of Nigerians, which amounts to 62.66 million, now live in urban centres.

The phenomenal rise in population, number and size of cities over the past few years have manifested in the acute shortage of dwelling units, resulting in high rents and other ills such as poor urban living conditions, high crime rates, and low infrastructure services and so on. On the microlevel, it has been observed that house ownership is one of the priorities for most households and it represents the largest single investment for most (between 50\% and 70\% of household income). This observation by Abimaje, Joshua, Akingbohungbe, Baba, \& Ndalai (2014:32) has become very significant when it is realised that Nigeria's per capita income has declined (currently N3, 000.00) as well as the real income of the average Nigerian. They also point out that the rapid upswing in building materials prices in the last five years has further reduced most Nigerians' affordability. It is relating annual requirements for housing with the Gross Domestic Product of N82.53 billion in 1988 and 85.82 billion estimates for 1989. Over 88billion in 1991 and per capita income of N3,000.00, financing becomes a significant factor of the problem, especially long-term funding. Abimaje, Joshua, Akingbohungbe, Baba, \& Ndalai (2014:32). Except for how to finance the construction of housing for all income groups effectively, the housing affordability problem is bound to escalate further and, consequently, increase the homelessness rate.

According to the Managing Director of Federal Mortgage Bank of Nigeria (FMBN), the housing deficit is estimated at between 17 to 20 million housing units, increasing annually by 900000 units, with a potential cost of N6 trillion (US\$16 billion). Almost half of Nigeria's population lives in cities, and it continues to witness a disproportion in supply and demand between social,-economic brackets. While a newly built development in a high-income area like Ikoyi in Lagos is reportedly 60 per cent empty, overcrowding is a major issue in many poorer areas. This leads to increased rural areas' conversion to semi-urban and urban spaces, often without the necessary plans and policies. Nigeria has a low homeownership rate of 25\%, lower than that of Indonesia (84\%), Kenya (73\%), and South Africa (56\%). (Gimba Yau' Kumo, 2018) The major issues that continue to affect Housing in Nigeria include constraints related to the high cost of securing and registering secure land title, inadequate access to finance, slow administrative procedures, and the high cost of land. (EFInA, 2017)

More than half of Nigeria's estimated population of 198 million live on less than US\$1 a day. The unemployment rate increased from $10.4 \%$ in 2016 to $18.8 \%$ in 2017. (Trading Economics, 2018) This situation coupled with the high quality of unemployment, the minimum wage remains at N18 000 (US\$60.28) per month, which has remained constant for the past six years, even with a high and increasing inflation rate currently at $11.6 \%$. Home purchase and rent prices have grown ahead of general inflation. A standard three-bedroom, middle-income apartment in urban locations now commands a rent of approximately US $\$ 5000$ per annum and a purchase price of US\$100 000. Overall, both at the state and federal level, the administration has a strong push to focus interventions on lowerincome earners aspiring to be homeowners and have been traditionally sidelined by the property market that is predominately controlled used by the elite. However, new housing construction remains limited in supply and prohibitively expensive for middle- and lower-income households. Fifty to sixty percent of total construction inputs go to building materials.

As a result of the high cost and limited production of affordable housing in Nigeria, $51 \%$ of Nigerians live in rented accommodation, 40\% of whom are paying between N20 000 (US\$55.56) and N100 000 (US\$222.22) yearly. (Kolawole Y., 2014) With most of the population forced to rent and low regulatory monitoring regarding rentals, landlords and estate agents dictate the market.

In Nigeria, neither the Government nor the private sector provides sufficient housing units, especially for the masses that need and demand it. Formal housing production is at approximately 100 000 units per year, and this is highly inadequate because at least 1000000 units are needed yearly to bridge the 17 to 20 million housing deficits by Government's target date of 2033 (if the population continues at its annual growth rate of 3.5\%). It is estimated that it will cost US\$363 billion to curb the current housing deficit, and the number is expected to keep growing. (AHFY, 2018). In line with this, this paper seeks to investigate homelessness in Nigeria and how the lack of affordable housing has contributed to it. 
The adequate shelter has always been one of man's basic needs; it is a significant component for human survival and measuring a good living standard. However, most urban centres' cost is higher than what an average Nigerian can afford. The income of an employee determines his ability to afford a house. Where per unit price of a building is abnormally high as we have today, the simple implication is that few people will be able to afford it (Bello, 2008). The limited finance available will not be able to spread around the potential homeowners. The gap between income and shelter cost in Nigeria is vast, and this has eliminated the low-income earners from the housing market. According to Bello (2008), the high price had been attributed to the following: Rising cost of building materials, the inflation rate in the economy, increased space and quality standards adopted by designers, fees of professionals involved in designs and construction, the excessive profit of contractors. The average income of Nigerians is too low to support buildings' construction (Opaluwa, 2010). Many even find it difficult to cope with regular and prompt rent payment. This makes the average Nigerian's aspiration to own a house or occupy an adequate rented apartment elusively.

As a result of the preceding, many have become homeless as they live in the street, temporary accommodation, squat or resort to living in the slum. The implication of this is a tremendous influence on the health, efficiency, social behaviour, satisfaction, productivity, and general wellbeing of the individual and the community. The need to ensure decent and affordable shelter to the people, particularly the urban poor, is central to improving both living standards and societal development. This will solve the challenge of homelessness.

This study aims to assess the level of homeless as a result of unaffordable housing in Nigeria. Mowe is a case study and was examined for the impact of unaffordable housing on the homeless. This aim is set out to achieve the objectives of this study, which is:

1. To find out the dimensions of homelessness in Mowe, Ogun state

2. To investigate the level of homelessness as a result of unaffordable Housing in Nigeria

3. To find out the influence of affordable housing on homelessness

4. To determine the strategies that can be used to ensure affordable Housing in Nigeria

\section{HOMELESSNESS, AFFORDABLE HOUSING AND RESIDENTIAL BUILDING COMPLEX}

Adequate housing is a vital component in creating a healthy and stable society; however, as crucial as very few families have access to decent shelter, they can call home. Many are on the street, open to the effect of rain and sun at various times. Their inability to provide protection has rendered them homeless. Rehman and Gahagan (2003), stated that homelessness is "the lack of a safe place where individuals and families can grow and contribute to the 'quality of life' in their community". The "homeless", as defined by the United States Federal Code 42 (2006), "is an individual who lacks a fixed, regular, and adequate nighttime residence". In 2009, at the United Nations Economic Commission for Europe Conference of European Statisticians (CES), held in Geneva, Switzerland, the Group of Experts on Population and Housing Censuses defined homelessness as:

i. Primary homelessness (or rooflessness). This category includes persons living in the streets without a shelter that would fall within the scope of living quarters;

ii. Secondary homelessness. This category may include persons with no usual residence, which frequently moves between various accommodations (including dwellings, shelters, and institutions for the homeless or other living quarters). This category includes persons living in private homes but reporting 'no usual address' on their census form.

Evidence from the literature shows that homelessness is predominantly an urban phenomenon. This is partly because of the commercialisation of land and housing markets in urban centres. Studies have shown that homelessness among families with children increases in low-income and high-income countries despite their affluence (National Coalition for the Homeless, 1999). It is a common feature in many regions of the world for people to live in crowded cabins which pass for homes. In areas like Mushin, Maroko, Oshodi and Ajegunle in Lagos State, Nigeria, tables have taken the place of beds, and floods occasioned by light heavy rainfalls take over rooms. Again, many Lagosians live under the countless bridges in the city. These people wake and retire daily to these bridges. In Diobu in Port- 
Harcourt, as in Brigade in Kano, Mowe, oke ilewo, Owode in Ogun State people live in squalor and refer to it as shelter. It is the same in Uno-Okpete in Enugu, Kawo and Agwan Saraki in Kaduna. People live in undesirable situations for human habitation, but this ugly situation is not peculiar to Nigeria.

The United States Department of Housing and Urban Development (HUD) policymakers stated that for a housing scheme to be affordable, the family should pay nothing more than $30 \%$ of its total income on rent and utilities. They own their own house, not more than $30 \%$ of their mortgage payment, insurance, taxes and utilities. This definition recognises the fact that every household has additional essential expenses to keep. Housing is thus affordable only if it meets this $30 \%$ test. Families that pay more than $30 \%$ of their income on housing are considered cost burden and may have difficulty affording other necessities, such as food, clothing, transportation and medical care (HUD, 2005). Cox and Partelich (2010) believe that housing prices should not exceed three times gross annual household income for a metropolitan area to rate as affordable and ensure that housing bubbles are not triggered.

In plain terms, AHURI (2004) states that housing affordability refers to households' capacity to meet other necessary living costs. Thus, it will be seen that the housing affordability issue is a crucial determinant of the quality of life of people.

It is crucial to state that while the state governments-built estates are more or less allocated to civil servants on an owner-occupier basis, the ones built by private developers are sold at exorbitant rates. This situation is explained by Adejumo (2008) when he asserted that, in all cases, the houses are not for rent. Still, for sale, because these developers have taken large loans from banks to finance their building projects, their objective is necessary to get a quick return on their money. Hence they prefer to sell these houses, usually at high prices, to ensure they have a 50\% profit. After completion of the sale, they typically have a $100 \%$ profit, if not more. This leaves Nigerians who are not civil servants and are not rich in cold inadequate shelter matters. This, in turn, will result in homelessness.

Residential building complex developments are also referred to as composite developments. The stories usually consist of a large and deluxe commercial complex, shopping malls, car park, or resident clubhouses built underneath residential tower blocks. The arrangements have achieved two primary objectives. Firstly, the composite developments are very welcomed, since it provides residents with necessary facilities and support for their daily life. It is a unique lifestyle in this small but dynamic metropolis. Second, the rentals you get from commercial properties provide an attractive return on investment. Therefore, compound developments hold a leading position in the competitive real estate market in terms of developer mindset-diagram in figure 1 shows a typical Schematic of the combined story. Building structures can be divided into three main areas. These are podium floors, transfer plates, and high-rise residential buildings. Generally, truss structures that can allow flexibility of space planning are used for walkway structures. For residential buildings, shear walls and rod walls are windproof and provide requirements for partitions and fire protection. Transfer plates are then manufactured to separate and transfer loads from residential tower blocks to podium structures. In order to maximise rental performance, podium floors typically occupy nearly the entire site area, leaving limited space for contractors to create on-site production facilities. Planning for on-site production is increasingly complex. The characteristics of a construction project cannot be easily identified or determined through multidimensional design information. (A. Leung \& C.M. Tam, 2010) 


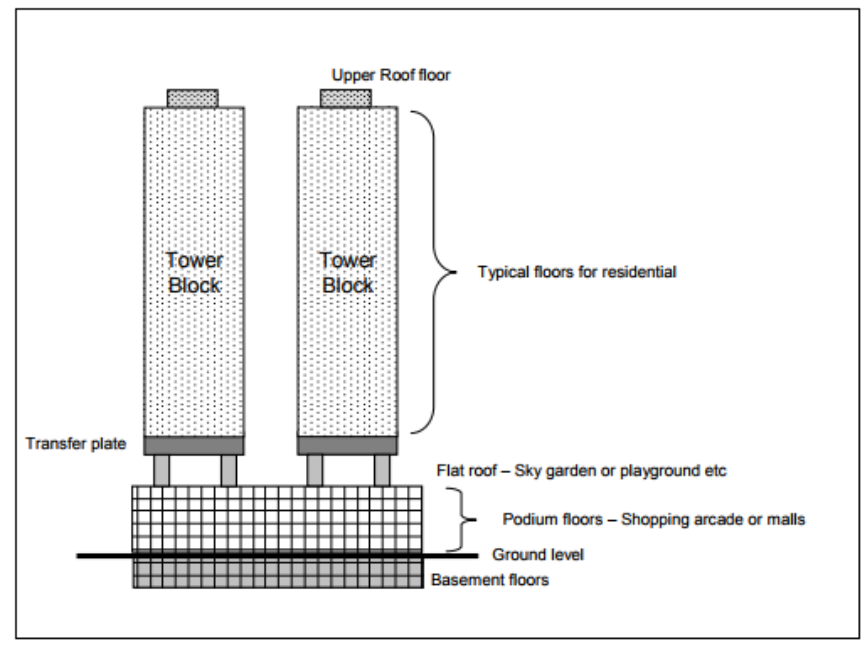

Fig. 1: A Typical Order for Multi-function Development Source: A. Leung \& C.M. Tam, (2010)

\section{THE CHALLENGE OF AFFORDABLE HOUSING}

Affordable Housing is Housing of a reasonable quality that is affordable to people on modest or low incomes. It includes various kinds of housing provision, each with its eligibility criteria for meeting different needs, (Padmini and Barrie 2016). Nearly three decades later, UN-Habitat is currently developing a Global Housing Strategy (GHS) for 2025. One of the main objectives for the strategy is the decentralisation of housing production to include various housing solutions matching practical demands. Despite significant efforts, the Government is still the largest or only affordable housing provider in most developing countries. The need for decent housing for the urban poor in developing countries is enormous, and if the public sector itself was to try to meet that need. This doesn't mean that no private developer is providing housing facilities, but they are having challenges making it affordable. Some of the challenges are:

- Availability of low cost serviced land

- Dual taxation

- No control on the escalation of construction cost and low Quality of Buildings

- Strenuous Land Use Act and Documentation Process

- Shortcomings/shortage of Mortgage Institutions coupled with ineffective Housing Budget

- Rural-Urban Migration/Urbanisation

- Inadequate Implementation of Planning Policies by the institutions charged with development plans in Nigeria

- Lack of Enlightenment of people on best developmental practice and policies

- High Population Growth, consequently leading to Inadequate and deficiency of housing required. 


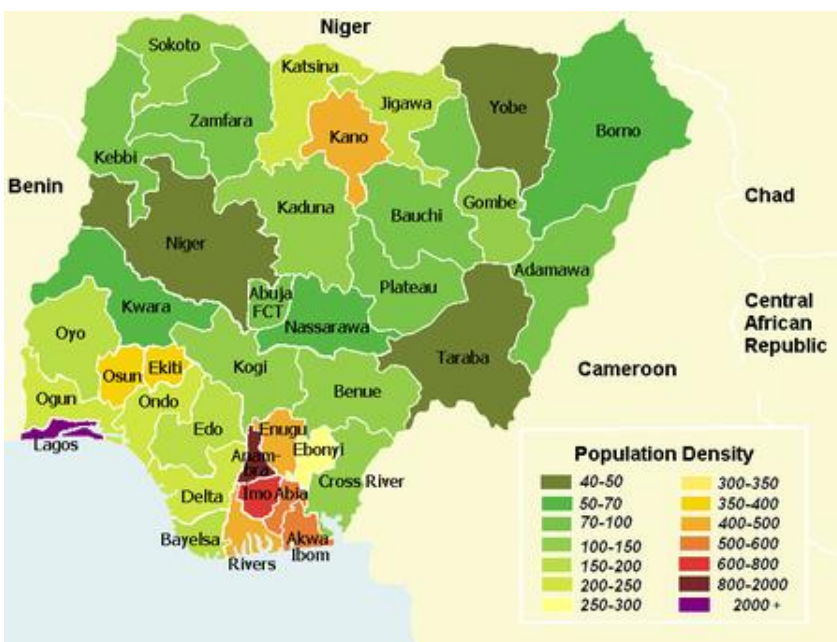

Fig. 2: Population Density of Nigeria. Source: Wikipedia, 2019

\section{METHODOLOGY}

The study utilised a structured questionnaire to collect the necessary data. This was administered in seven randomly selected neighbourhoods of Ogun state. These are Redemption camp, Imedu_Nla, Gbegira, Lotto, BONN Village, Abule Alfa and Mowe. The questionnaires were systematically administered to the respondents living in temporary accommodation, abandoned vehicles etc., in the selected significant streets in these areas. Out of the seven regions, a total of 28 questionnaires were administered in each of three designated areas, and 29 questionnaires were administered in each of the other four chosen areas totalling 200 questionnaires. Out of these, 198 were returned for analysis. Thus, the sample size is 200 .

The variable considered in this work is the house type of the respondents, the respondents' income, and the percentage of income spent on the respondents' accommodation. The data for this study were analysed using descriptive statistical tools such as frequencies and percentages.

\section{RESULTS AND DISCUSSION}

The result of the study indicates in the main thrust which

Table 1: Place of residence before the temporary shelter

\begin{tabular}{lll}
\hline Response & Frequency & Percentage (\%) \\
\hline South West & 120 & 60.6 \\
South East & 31 & 15.7 \\
South-South & 24 & 12.1 \\
North & 23 & 11.6 \\
Total & $\mathbf{1 9 8}$ & $\mathbf{1 0 0 . 0}$ \\
\hline
\end{tabular}

Table 2: The period of out of a shelter

\begin{tabular}{lll}
\hline Response & Frequency & Percentage (\%) \\
\hline 1 month & 44 & 22.2 \\
2-6 month & 40 & 20.2 \\
7-12 month & 35 & 17.7 \\
1-2 years & 58 & 29.3 \\
2 years \& above & 21 & 10.6 \\
Total & $\mathbf{1 9 8}$ & $\mathbf{1 0 0 . 0}$ \\
\hline
\end{tabular}

Table 3: lack of affordable housing can result in homelessness

\begin{tabular}{lll}
\hline Response & Frequency & Percentage (\%) \\
\hline Yes & 158 & 79.8 \\
No & 40 & 20.2
\end{tabular}


Table 4: Lack of affordable Housing will encourage people to secure temporary shelter

\begin{tabular}{lll}
\hline Response & Frequency & Percentage (\%) \\
\hline Strongly Agree & 97 & 49 \\
Agree & 67 & 33.8 \\
Neutral & 34 & 17.2 \\
Disagree & - & - \\
Strongly Disagree & - & - \\
Total & $\mathbf{1 9 8}$ & $\mathbf{1 0 0 . 0}$ \\
\hline
\end{tabular}

Table 5: Is temporary shelter free?

\begin{tabular}{lll}
\hline Response & Frequency & Percentage (\%) \\
\hline Yes & 198 & 100 \\
No & - & - \\
Total & $\mathbf{1 9 8}$ & $\mathbf{1 0 0 . 0}$ \\
\hline
\end{tabular}

Table 6: lack of affordable housing will increase the level of homelessness in Nigeria

\begin{tabular}{lll}
\hline Response & Frequency & Percentage (\%) \\
\hline Yes & 143 & 72.2 \\
No & 55 & 28.8 \\
Total & $\mathbf{1 9 8}$ & $\mathbf{1 0 0 . 0}$ \\
\hline
\end{tabular}

Table 7: Increased level of homelessness will result in an overcrowded temporary shelter

\begin{tabular}{lll}
\hline Response & Frequency & Percentage (\%) \\
\hline Strongly Agree & 71 & 35.9 \\
Agree & 102 & 51.5 \\
Neutral & 21 & 10.6 \\
Disagree & 4 & 2 \\
Strongly Disagree & - & - \\
Total & $\mathbf{1 9 8}$ & $\mathbf{1 0 0 . 0}$ \\
\hline
\end{tabular}

Table 8: Reason for homelessness

\begin{tabular}{lll}
\hline Response & Frequency & Percentage (\%) \\
\hline Health-Related issues & 20 & 10.1 \\
Alcohol and drugs issues & 3 & 1.5 \\
Loss of a loved one (breadwinner) & 11 & 5.6 \\
Unemployment & 76 & 38.4 \\
Victim of Natural disaster, e.g. Flooding & 14 & 7.1 \\
Lack of Affordable Housing & 69 & 34.8 \\
Relationship breakdown & 5 & 2.5 \\
Total & $\mathbf{1 9 8}$ & $\mathbf{1 0 0 . 0}$ \\
\hline
\end{tabular}

Table 9: Is affordable housing possible in Nigeria

\begin{tabular}{lll}
\hline Response & Frequency & Percentage (\%) \\
\hline Yes & 147 & 74.2 \\
No & 51 & 25.8 \\
Total & $\mathbf{1 9 8}$ & $\mathbf{1 0 0 . 0}$ \\
\hline
\end{tabular}

\section{DISCUSSION OF FINDINGS}


Findings on research question sought to find out the influence affordable housing has on homelessness in Nigeria. The answer to the above research question is found in Tables 1, 2, 3, 4 and 5. The table shows respondents' place before becoming homeless, the majority of the sampled respondents $(60.6 \%)$ stated that they lived in south-west before, $15.7 \%$ said they are from the South East, $12.1 \%$ are from the South-South while $11.6 \%$ are from the North. This means that every region of the country has its share of homelessness, but homelessness resulting from affordable housing is more South West. Also, on the issue of being homeless, as seen in Table 2, most of the sampled respondents (29.3\%) have been lost for as long as $1-2$ years. $22.2 \%$ have been homeless one month, $20.2 \%$ said they have been homeless for 2-6 month, $17.7 \%$ have been homeless for $7-12$ month while $10.6 \%$ have been homeless for 2 years and above. From the above findings, it is evident that people can be homeless for an extended period without having the solution to the problem; hence they remain in a temporary shelter for long

On the issue of whether lack of affordable housing can result in homelessness, as seen in Table 3, most of the sampled respondents (79.8\%) said they agree that lack of affordable housing can result in homelessness while $20.2 \%$ said no. This shows that without any reasonable doubt, affordable housing is a cause of homelessness in Nigeria.

On the issue of whether lack of affordable housing will encourage people to secure temporary shelter, the majority of the sampled respondents (49\%) strongly agree that lack of affordable housing will encourage people to secure temporary shelter. $33.8 \%$ agree that lack of affordable housing will encourage people to secure temporary shelter, $17.2 \%$ are neutral and lack affordable housing will encourage people to secure temporary shelter. The importance of the above findings suggests that the lack of affordable housing will encourage people to secure temporary shelter, which is mostly free and safe for homeless people. This is seen in table 5, which shows whether the temporary accommodation (the temporary accommodation provided by Redeem Christian Church of God) is free or with a price. All the sampled respondents (100\%) said that the capacity is free. This is in line with the findings of (Abiodun, 1997; Jiboye, 2009) they asserted that this incidence of population explosion has, therefore, created severe developmental problems, ranging from inadequate infrastructure, deterioration of available social amenities, and more importantly, acute shortage of decent and affordable housing.

Analysis from research question two shows homelessness due to a lack of affordable housing in Nigeria. This question is answered by the quantitative analysis provided in tables 6,7 , and 8 . This table shows whether a lack of affordable housing will increase homelessness in Nigeria. A majority of the sampled respondents (72.2\%) said that a lack of affordable housing would increase homelessness in Nigeria. In comparison, $28.8 \%$ said they disagree that the lack of affordable housing will increase homelessness in Nigeria. This means that as long as housing remains unaffordable, homelessness will stay on the increase.

Similarly, the increasing level of homelessness will result in the overcrowded temporary shelter, as seen in table 6. Majority of the respondents agreed that increased homelessness would result in overcrowded temporary shelter represented by $102(51.5 \%)$ and strongly agree by $71(35.9 \%)$ of the respondent. 21(10.6\%) of the respondents are indifferent about whether the increased level of homelessness will result in an overcrowded temporary shelter, and 4 (2\%) of respondent sent said they disagree. This is why (Abiodun, 1997; Jiboye, 2009) stated that this incidence of population explosion had created severe developmental problems, ranging from inadequate infrastructure, deterioration of available social amenities, and more importantly, acute shortage of decent and affordable housing. The situation has resulted in overcrowding, the proliferation of deprived settlements, increased poverty and high crime rates and, to an extreme case, outright homelessness.

On the issue related to the reason behind homelessness, which is seen in table 7, most of the respondent represented by $76(38.4 \%)$ said that unemployment is the reason for being homeless. Close to this is the $69(34.8 \%)$ of the respondent, who says lack of affordable housing is the reason behind their homelessness. This means that most of the respondents lacked affordable housing because of lack of employment, part of which is a significant issue in Nigeria.

A recent survey carried out by the researcher over a random selection of people within the work frame of housing investors, individuals, Architect and government parastatals all located within the study area agreed that properly planned high rise Residential building complex situated a strategic 
location could be a start to the solution of Housing in Nigeria at large which will cater for both residential and other basic necessity of everyone all at the same time

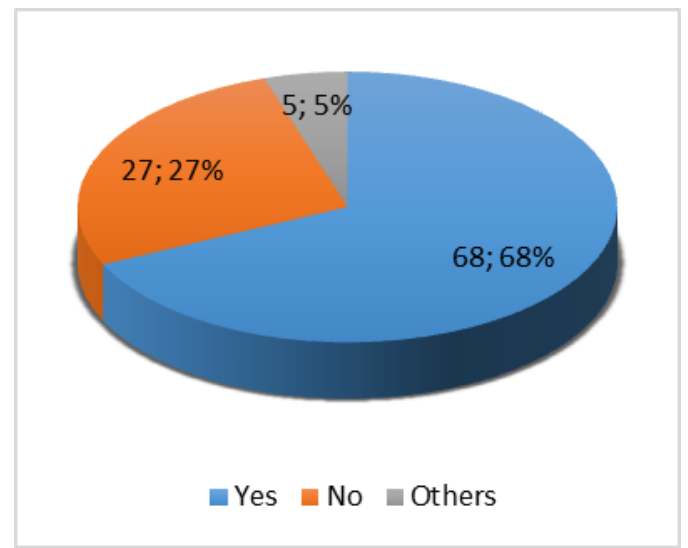

Fig. 3: Survey of the use of High rise building in solution to the Housing problem Source: Authors Research survey.

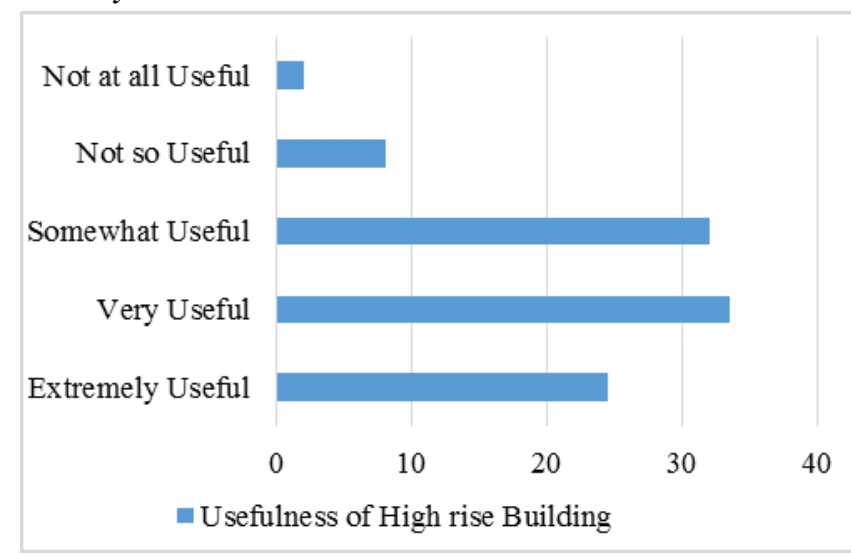

Fig. 4: Survey of Usefulness of Residential building complex in solving Housing problems Source: Authors Research Survey

From figure 3, about $68.42 \%$ believe the solution lies in verticality rather than horizontality, especially areas of a dense population due to unavailability of land and for easy achievement of housing goals for all. In comparison, $26.32 \%$ believe it is not, with reasons such as Nigeria is blessed with a landmass. It can and should be utilised for getting the sustainability effect on the environment, and 5.26\% are indifferent about it. Figure 4 looks at the coefficients based on the usefulness, availability, affordability, and it as a tool to solve housing problem $33.68 \%$ of the respondents find it a handy tool, $32.63 \%$ find it somewhat useful. In comparison, $24.21 \%$ of respondents find it extremely useful, with just about $7.37 \%$ finding it not so helpful and $2.11 \%$ not applicable.

Apart from the above solution, Sherif (2018) and Temi-Ojo (2018) established that creating a Reliable Mortgage system, Total implementation and Review of National Housing Policy, Easy Land and House Regulations, Implementation of Public Housing Projects, Provision of Adequate Infrastructures, Genuine Research Policy, Private Sector Full Participation, Locally Manufacturing building materials and Provision of Rental houses are the leading solution to housing and Residential building complexes in Nigeria. While Ezeigwe, Patrick C.(2015) further recommended that poverty eradication programmes be implemented, monitored and periodically evaluated for success. The Government should ensure that housing policies are met, issues with getting lands, and occupancy certificates should be made easier. In the same vein, the Government should provide opportunities for speeding up construction and reducing the cost of building, and that private sector collaboration is of utmost importance. Nwamanah Dinim (2018) and Temi-Ojo (2018) suggested that research institutes should be encouraged to exploit local raw materials and produce alternative building materials, critical 
review of rural and urban housing policies, National development plan should consider housing problems, Rural is development to reduce rural-urban drift, Federal Mortgage Bank of Nigeria, Federal Housing Authority, Federal Mortgage Finance Limited, Urban Development Bank and other parastatals should perform more effectively.

The advantages of using high rise building complexes can not be over-emphasized especially in areas with severely large population and small land mass. Lagos Nigeria happens to be one of such and require this phenomenon to be able to cater for the teeming population as a lot could be catered for with a small land mass of one acre in comparison to the use of such acre as an Estate as the case had been from time past. More occupants would be catered for and more green buildings could be encouraged.

\section{CONCLUSION}

Housing is one of life's necessities notwithstanding the economy's condition, which poses a challenge mostly in urban centres where homelessness, overcrowding, slum, low-quality housing units, and inadequate infrastructure are the order of the day. The causal force is not far fetched to include but not limited to the Land Use Act. Documentation Process, Infrastructural Development, High Cost of Building Materials and Poor Quality of Buildings, Shortcomings of Mortgage Institutions \& Ineffective Housing Budget, Rural-Urban Migration/Urbanisation, Inadequate Implementation of Planning Policies, Lack of Enlightenment, High Population Growth; The need to ensure decent and affordable shelter to the people, is therefore central to the achievement and improvement of both living standards and societal development.

For Residential building complexes to be successful, a country like Nigeria must have a stable macroeconomic environment, moderate inflation rate. Full implementation of the 2006 Nigerian National Housing Policy, the policy adjusted such as the amortisation period which was 25years under the previous policy was jacked up to 30years, interest on NHF loans to PMI's were scaled down from $5 \%$ to $4 \%$ while the lending rate to contributors is reduced to $6 \%$ from previous $9 \%$. The policy also stated that residential building complexes development must be easily accessible and affordable, developing and promoting a national housing market among several others.

Thus, if housing must be affordable, the overall cost of the construction must be considered. According to (Adedeji 2008a), the use of interlocking concrete blocks as an alternative to mortarbedded masonry must be regarded. This is because it accelerates the constructions process and improves productive hour with minimal wastages. There is also the need to establish factories that will produce standard components of building materials, reducing importation and outsourcing. And suggestions architecturally is to increase verticality, i.e. high rise buildings and discourage horizontality in building construction to achieve more with less space especially in the densely populated area of the country, other suggestions were to establish a reliable mortgage system, implement all Housing policy without prejudice, Ease land and house regulation, encourage private sector participation, improve and encourage locally made building materials not forgetting provision of adequate infrastructures. This solutions may outrightly not eradicate the problems of housing and multifunctional building but would be a start in the right direction in providing sufficient accommodation for all and sundry

\section{RECOMMENDATION}

Based on the preceding that, affordable housing is a significant challenge of homelessness, this paper, therefore, makes the following recommendations:

1. The ministry of housing needs to step up research and development of indigenous technology to enhance local building materials production.

2. Funds should be made available for research on lowering the cost of Residential building complexes construction.

3. State and local Government should be involved in the design and formulation of Residential building complexes policies. 
4. Access to Residential building complexes should be democratised. The Government should increase land access for all Nigerians because when there is excellent access to land, its present high cost will be reduced.

5. Housing loan board should be established and adequately funded to grant public and private workers loans to purchase houses and make instalment repayment over a while.

6. Encourage people to go for architectural consultancy and advice as they embark on creating their homes based on their purse.

7. Create and encourage Residential building complexes availability, especially in areas with a dense population.

\section{REFERENCES}

1. A. Leung and C.M. Tam (2010). Modern Multi-Function Building Developments. Published in Int. Journal for Housing Science, Vol.34, No.3 pp. 151-162, 2010 Published in the United States. Retrieved at http://www.housingscience.org/html/publications/pdf/34-3-1.pdf

2. Abiodun, J.O., 1985. The provision of housing and urban environmental problems in Nigeria. Urban and Regional Planning Problems in Nigeria. Ile-Ife. University of Ife Press Ltd.

3. Adedeji Y.M.D (2008a) Interlocking Masonry: Panacea for sustainable, low-cost housing in Nigeria. Pakistan Journal of Social Sciences 5(8): 744-750, ISSN: 1683-8831

4. Adedeji Y.M.D (2008b) Factors for the preference for interlocking masonry in Housing delivery in Nigeria. Environmental Research Journal 2 (6): 284-289, ISSN:1994-5396

5. AHFY (2018). Africa Housing Finance Yearbook 2018 accessed from the internet at http://housingfinanceafrica.org/app/uploads/Nigeria-2018-Final.pdf (Accessed March 23, 2019)

6. EFInA (2017). Key Findings: EFInA Access to Financial Services in Nigeria (A2F) 2016 Survey. http://www.efina.org.ng/assets/A2F/2016/Key-Findings-A2F-2016.pdf (Accessed September 24 2018).

7. Ezeigwe, Patrick C. (2015). Evaluation of the Causes of Housing Problems in Nigeria: A Case Study of Awka the Capital City of Anambra State. Journal of Economics and Sustainable Development www.iiste.org ISSN 2222-1700 (Paper) ISSN 2222-2855 (Online) Vol.6, No.20, 2015

8. Gimba Yau' Kumo, paper presented at the 6th Abuja Housing Show.

9. Jiboye, A. D. (2009). The challenges of sustainable housing and urban development in Nigeria. (pp. 23-27).

10. Kolawole, Y (2014). 51\% of adult Nigerians live in rented houses - NOI Polls. https://www.vanguardngr.com/2014/11/51-adult-nigerians-live-rented-houses-noi-polls/ 24 Nov 2014. Vanguard. (Accessed September 24 2018).

11. Konadu-Agyemang, K., Noonam, J.M., \& McCord, D. (1994). Social Housing and Social Integration in the Durham Region of Ontario, Canada. Ekistics,366, 367, 145-155.

12. Nwamanah Dinim (2018). 10 Problems of Housing in Nigeria and the possible solution. Extract from the internet at https://infoguidenigeria.com/problems-housing-nigeria/ written on July 13, 2018

13. Osasona, C., Ogunshakin, L., \& Jiboye, A. (2007, November). The African Woman's right to security through sanitation. From the dwelling unit to the neighbourhood. In Conference proceeding on, Right to Live in Africa. Trieste (pp. 9-10).

14. Sherif (2018). Housing problems in Nigeria and solutions. Extract from the internet at https://naijaquest.com/housing-problems-in-nigeria/ published on August 30, 2018

15. Temi Oni-Jimoh and Champika Liyanage (November 28 2018). Urbanisation and Meeting the Need for Affordable Housing in Nigeria, Housing, Amjad Almusaed and Asaad Almssad, IntechOpen, DOI: 10.5772/intechopen.78576. Available from: https://www.intechopen.com/books/housing/urbanization-and-meeting-the-need-for-affordablehousing-in-nigeria

16. The Nigeria Constitution, 1999, Section 16 (2) 
17. Trading Economics (2018). Nigeria Unemployment Rate, 2006-2018. https://tradingeconomics.com/nigeria/unemployment-rate (Accessed September 24 2018).

18. UN-Habitat. (2003). The challenge of slums: Global report on human settlements 2003. Nairobi, Kenya: United Nations Human Settlements Programme (UN-Habitat).

19. United Nations (2010). The State of African Cities 2010. Nairobi, UN-HABITAT. 